\title{
Important Morphological Characters in Several Species of Cassiinae (Leguminosae) in South-Western Nigeria
}

\author{
Sefiu Adekilekun SAHEED, Herbert Chukwuma ILLOH \\ Obafemi Awolowo University, Faculty of Science, Department of Botany, Ile-Ife 220005, Nigeria; saheed@oanife.edu.ng (corresponding author)
}

\begin{abstract}
Macromorphological characters of some species of Cassia L. emend. Gaertner, Senna Miller and Chamaecrista Moench occurring in South Western Nigeria were studied. The aim was to search for stable, distinctive and diagnostic characters for the identification of these genera and their species. Qualitative characters were noted and recorded while quantitative observations were done by the use of a metric ruler and the measurements were taken to the nearest centimeters. The habit ranges from all shrubs in Senna, shrubs and herbs in Chamaecrista while the Cassia species studied are all trees. The shape of the leaflet apex varies in both Senna and Cassia species, while it is distinctly mucronate in Chamaecrista genus. Occurrence of foliaceous stipule in the genus Chamaecrista clearly separates it from Senna and Cassia, which are completely exstipulate. In general, other characters such as number of leaflet pairs, length and width of leaflets, leaflet base, and number of leaflets lateral nerves revealed generic distinctions. Others include the degree of hairiness in sepals, petals shape, types of inflorescence, fruit shape and fruit length. The attributes that delimits the species are mainly quantitative. The results of this investigation suggest macromorphological characters that clearly enhance the taxonomy of these genera and their species and they can be subsequently employed in their delimitation.
\end{abstract}

Keywords: Cassia, Chamaecrista, floral pattern, habit, morphological characters, Senna, taxonomy

\section{Introduction}

Prior to the work of Irwin and Barneby (1981), the genus Cassia used to be a very large genus that comprises of about 500 to 600 species (Airy-Shaw, 1973). The genus ranks among the 25 largest genera of the dicotyledonous plants (Irwin and Turner, 1960). Bentham (1871) and Bentham and Hooker (1876) did a lot of work in the general classification of this genus, these two works recognizes that there are three subgenera in these genus, vis: Cassia, Senna and Lasiorhegma. In West Africa, the genus contains about 22 indigenous species apart from those introduced or cultivated (Hutchison and Dalziel, 1958). There is a great diversity of habit within the genus ranging from trees approaching $34 \mathrm{~m}$ in height to prostrate annual herbs. Some members of the genus are important ornamentals e.g. Cassia siamea (Olorode, 1984), this plant is used for afforestation programmes in drier areas. Other members of the genus could be useful as commercial timbers and a great number of them have been reported to be of great use in herbal medicines especially as laxatives and in the treatment of skin diseases (Ayensu, 1978; Olorode, 1984; Di Stasi et al., 1989).

Paripinnate compound leaves and many leaflets characterize the genus; however, Oloruntoba (1984) reported a simple leaf accession to which Adebowale (2000) suggested that the accession is probably a product of recent reverse mutation event in Cassia occidentalis because of its restricted distribution. The flower is one of the constant characters found in this genus despite its great diversity of form. The flowers are hermaphroditic and generally monocarpellate, zygomorphic and arranged in conspicuous axillary or terminal racemes (Hutchison and Dalziel, 1958). The stamens are ten in number and they are heteromorphic, some may be reduced to staminodes (Hutchison and Dalziel, 1958). The fruit that is many seeded is a pod of varying lengths that may be from $3 \mathrm{~cm}$ to $1 \mathrm{~m}$ and may assume different shapes and sizes (Olorode, 1984).

Interestingly in 1981, Irwin and Barneby subjected the genus into some nomenclatural and taxonomic changes that eventually led to the revision of the genus Cassia (Irwin and Barneby, 1982) and splitting of the genus into smaller genera viz: Cassia, Senna and Chamaecrista. However, Lock (1988) observed that series of problems have arisen due to this name changes because many taxonomists especially on the African flora may prefer to continue to use Cassia in its broad sense, which would be acceptable if there was no overlap between floras of Africa and South America. However, many species in this genus are endemic in the tropics because of dispersal or deliberate introduction as exotic plants, this will further results into confusion, as several species will be given different names in different continents (Lock, 1988). Additional information on this very important group of plants, which will provide insights into detailed diagnostic characters that would be of help to taxonomist after this new classification are scanty. Therefore this study aims to provide a comprehensive description of the macromorphological characters of the new Cassia, Senna and Chamaecrista species, thereby adding more to the scanty information on the morphology 
48

of these genera and eventually their taxonomy. We equally hope that the outcome of this study would be employed along with other diagnostic features for proper identification and classification of these genera and their species as well as to justify or otherwise, the separation from the initial genus Cassia as defined by Bentham (1871) and Betham and Hooker (1876).

\section{Materials and methods}

Five species were selected from the genus Senna and they are: S. alata (L.) Roxb, S. hirsuta (L.) S. obtusifolia (L.) Irwin and Barneby, S. occidentalis (L.) Link and $S$. sophera (L.) Roxb. Three species were selected from the genus Chamaecrista namely C. kirkii (Oliver) Standley, $C$. mimosoides (L.) Greene and C. rotundifolia (Pers.) Greene, while two species from the genus Cassia were studied these are: C. fistula $\mathrm{L}$. and C. siberiana DC. All the specimens were collected from different location within South-Western part of Nigeria $\left(10^{\circ} 00^{\prime} \mathrm{N}, 8^{\circ} 00^{\prime} \mathrm{E}\right)$, an abridged listing of the specimens cited are shown (Tab. 1), dried herbarium specimens of all the species were also studied morphologically at the Obafemi Awolowo University Herbarium (IFE) and the herbarium at the Forest Research Institute of Nigeria, Ibadan (FHI).

The habit and habitat of each species were recorded. Qualitative morphological characters studied include: leaflet shape, base and apex, their margins, vein, petioles, fruit types, their shape and apex. Others characters studied include presence or absence of stipule, colours of petals, pedicel, epicalyx, sepals, style, filament, anther and stigma as well as the shapes of petals, sepals and epicalyx were also observed and recorded. Quantitative morphological characters measured include length and breadth of leaflets, length and diameter of fruits, petal, style and stamen lengths, this was done by the use of a metric ruler and the measurements were taken to the nearest centimeters. Counts were taken of the number of sepals, petals and epicalyx. Fresh materials collected in the field were pressed and processed immediately as voucher specimens and they were deposited at IFE herbarium after the photograph of a representative specimen of each species were taken and imported into Corel Draw 12 for presentation.

\section{Results}

The macromorphological features of each species are described in the following presentation, grouping them under their respective genera.

\section{Genus Senna}

\section{S. alata (L.) Roxb. (Fig. 1A)}

The plant is found cultivated around habitations because of its medicinal value or found as weed growing in wastelands, abandoned lands and along roadsides. The habit is mostly perennials, shrub, suffrutescent usually about $4.5 \mathrm{~m}$ high or more. The stem is greenish at top and woody below, glabrous; petiole is terete $2.6-10 \mathrm{~cm}$ long (Tab.2), connecting the leaflets. Leaf is paripinnate, exstipulate, leaflets about 5-12 pairs, arranged oppositely along a transverse ridge. The leaf is oblong to obovate at the base and the apex is mostly rounded, sometimes emarginate apex is found. The margin is mostly entire $6-18 \mathrm{~cm}$ long, 4.3-16 wide (Tab. 2). The venation shows primary veins that are straight in course with lateral veins been around 9-23 per leaflet mostly alternate some are opposite. The inflorescences are a terminal raceme (Tab. 3), compact, conspicuous with elliptic bracts ranging from $2.5 \mathrm{~cm}$ long and $1.2 \mathrm{~cm}$ wide. The pedicel is greenish, sparsely pubescent about $0.6 \mathrm{~cm}$ long while the sepal is about $1.3-1.7 \mathrm{~cm}$ long and $0.4-0.6 \mathrm{~cm}$ wide glabrous, yellowish, connate at base pentamerous, lanceolate. Petals are deep yellow, pentamerous, assymetrical about $1 \mathrm{~cm}$ long and $0.7 \mathrm{~cm}$ wide. The stamen is about $0.6 \mathrm{~cm}$ long, filament greenish brown, anther yellowish. Style is greenish about $1.3 \mathrm{~cm}$ long and the stigma dark brown. The fruit is a samaroid pod (Tab. 3), black when mature and dry, oblong in shape, $17-27 \mathrm{~cm}$ long and 1.4-2.0 $\mathrm{cm}$ wide.

\section{S. hirsuta L. (Fig. 1B)}

This is a weed commonly found near habitations, on roadsides, farmlands, wastelands as well as abandoned areas. They are shrub (Tab. 2), suffrutescent, mostly up to 2 $\mathrm{m}$ high, mostly annuals sometimes biennial or perennial. The stem is greenish at the top and woody brownish base, densely pubescent. The petiole is mostly polygonal 3.5-5.8 $\mathrm{cm}$ long. The leaf is paripinnate, exstipulate, leaflets arranged oppositely in 4-5 pairs, it is broadly lanceolate to ovate in shape, margin mostly entire, sometimes few minor serration present base acute, apex attenuate, $4.5-11 \mathrm{~cm}$ long, 2.6-5.2 cm wide (Tab. 2). The venation consist of primary veins that are straight in course with lateral veins in pairs ranging from 5-13 pairs per leaflets, mostly alternate, more prominent on the abaxial surface. Inflorescence is a raceme (Tab. 3). The pedicel is greenish, pubescent 0.6$1.2 \mathrm{~cm}$ long, sepals are greenish yellow, pentamerous, lanceolate densely pubescent $0.4-0.8 \mathrm{~cm}$ long and $0.2-0.4 \mathrm{~cm}$ wide, while petals is brilliant yellow, pentamerous, ovate to assymetrical, $0.7-1.6 \mathrm{~cm}$ long and $0.4-0.9 \mathrm{~cm}$ wide. The stamen is about $0.5-1.3 \mathrm{~cm}$ long, filament brown to dark brown, anther brownish yellow. The style is Greenish yellow, densely pubescent, stigma $1.5-2.3 \mathrm{~cm}$ long dark to black in colour, curved at the apex. The fruit is a flat pod (Tab. 3), yellowish brown, densely pubescent, about $17 \mathrm{~cm}$ long and $0.5 \mathrm{~cm}$ wide, apex acute.

\section{S. obtusifolia (L.) Irvin and Barneby (Fig. 1C)}

This is a weed commonly found along roadsides near habitations and wastelands. They are shrub, suffrutescent, mostly about $1.5 \mathrm{~m}$ high (Tab. 2), annual, sometimes biennial. The stems are greenish at the top and brownish at 
Tab. 1. Site description of some of the specimens cited

\begin{tabular}{|c|c|}
\hline $\begin{array}{l}\text { Senna } \\
\text { S. alata }\end{array}$ & $\begin{array}{l}\text { Daramola, IFE 13918, About } 12 \text { km on Moniya Iseyin Road. Oyo State. } \\
\text { Ogunyemi, IFE 3118, Ife Varsity, Near Ornamental Garden, Osun State. } \\
\text { Odewo et al. FH1 88147, Along Owode Road, Ogun State. } \\
\text { Ajulo OO FH1 102263, Road 7, University of Ife Quarters, Osun State. } \\
\text { Saheed 133, Beside Car Park, Osogbo Road, Offa, Kwara State (IFE) } \\
\text { Saheed 137, Ayedun Quarters, Dele-Dealer Junction Akure, Ondo State (IFE) }\end{array}$ \\
\hline S. hirsuta & $\begin{array}{l}\text { Akabogu AO IFE 3124, University of Ife Agric Farm, Osun State. } \\
\text { Guile DPM IFE 3126, Near University of Ife Campus, Ibadan. Oyo State. } \\
\text { Odewo et al. FH1 91160, Pillot Sawmill, High Forest, Akure Ondo State. } \\
\text { Latilo MG FH1 18222, Esie Forest Reserve, High Forest, Ilorin, Kwara State. } \\
\text { Saheed, 126, Along Lagos Road, Abeokuta, Ogun State (IFE) } \\
\text { Saheed, 138, Around Central Praying Ground. Agege Motor Road, Mushin Lagos State. (IFE) }\end{array}$ \\
\hline S. obtusifolia & $\begin{array}{l}\text { Faremi, IFE 3136, Remnant of Old Bussa Village Near Shagunu Research Station, Niger State } \\
\text { Hall, IFE 3134, South of Jebba on Ilorin Road, Ilorin, Kwara State. } \\
\text { Gbile, FHI 84319, Cleared Plot, Idiode Ijebu-Igbo. Ogun State. } \\
\text { Daramola et al. FHI } 78423 \text {, Near Federal Housing Scheme Calabar, Calabar River State. } \\
\text { Saheed, 113, Behind } 440 \text { Junction, Osogbo Road, Ede, Osun State (IFE) } \\
\text { Saheed, 116, Along Staff Quarters, FUTA, Akure, Ondo State (IFE) }\end{array}$ \\
\hline S. occidentalis & $\begin{array}{l}\text { Daramola, IFE 13037, O.A.U. Campus, Ile-Ife Osun State. } \\
\text { Faremi, IFE 3141, Shagumu Research Station, Ilorin Kwara State. } \\
\text { Magbagbeola et al. FHI 94866, Festac Village, Lagos State. } \\
\text { Olorunfemi et al. FHI } 84639 \text {, Iyere, Ondo State. } \\
\text { Saheed, 134, Ansar-Udeen, Primary School, Ijebu-Ode Ogun State (IFE) } \\
\text { Saheed, 142, Along Sango Road, Samonda Area, Ibadan, Oyo State (IFE) }\end{array}$ \\
\hline S. sophera & $\begin{array}{l}\text { Esiofor, FHI 19844, Share, Ilorin Kwara State. } \\
\text { Thomas: FHI 27057, Olobo, Alongside Path Beside Cocoa Farm, Ibadan, Oyo State. } \\
\text { Ajulo, FHI 102271, Ilare Street, Near Oduduwa College, Ile-Ife, Osun State. } \\
\text { Saheed, 121, Ayedun Quarters, Akure Ondo State (IFE) } \\
\text { Saheed, 155, Dumping Site / Uncompleted Building Alagbado area, Lagos State (IFE) } \\
\text { Saheed 161, Ago-Iwoye Road, by Ijebu-Ode-Ibadan Road Junction, Ogun State (IFE) }\end{array}$ \\
\hline $\begin{array}{l}\text { Chamaecrista } \\
\text { C. kirkii }\end{array}$ & $\begin{array}{l}\text { Guile, IFE, 3082b, University of Ibadan Campus, Ibadan Oyo State. } \\
\text { Faremi, IFE 3109, Erin-Odo Village on the way to the Falls Ondo State. } \\
\text { Gbile and Others, FHI 64104, Oro, Omun Aran, Kwara State. } \\
\text { Keay, FHI 22563, About } 3 \text { Miles East of Ondo, North of Akure road, Ondo State. } \\
\text { Saheed, 107, Beside Guest Houses, Kanji Lake National Park, Borgu. Niger State (IFE) } \\
\text { Saheed, 119, Collection from Ugbo-Uku Anambra State by Dr. H.C. Illoh (IFE) }\end{array}$ \\
\hline C. mimosoides & $\begin{array}{l}\text { Daramola, IFE 13060, Isua, Ipe Akoko Southeast Ondo State. } \\
\text { Faremi, IFE 3094, Near Iwo on Gbongan-Iwo road, Osun State. } \\
\text { Odewo et al. FHI 105769, FRIN Conservation Plot, Oloye, Badagri, Lagos State. } \\
\text { Gbile et al. FHI 94193, Obudu Cattle Ranch, Cross River State. } \\
\text { Saheed, 160, Kainji Lake National Park, Borgu Sector Along Hippo Pool, Niger State (IFE). } \\
\text { Saheed, 172, Akure-Ita Ogbolu-Ikere Ekiti Road, Akure, Ondo State. (IFE) }\end{array}$ \\
\hline C. rotundifolia & $\begin{array}{l}\text { Ogunyemi, IFE 14569, Moor Plantation, Ibadan Oyo State. } \\
\text { Sanford, IFE } 3115 \text { b, Ogbomoso-Ilorin Road, Kwara State. } \\
\text { Oyayomi et al. FHI 82357, Ikog-Nadagru Road, Lagos State. } \\
\text { Olorunfemi et al. FHI 86799, Orin Ekiti, Ekiti State. } \\
\text { Saheed, 165, Ansar-Udeen Primary School Ijebu-Ode Ogun State (IFE) } \\
\text { Saheed, 186, Around Senate Building FUTA Akure Ondo State (IFE). }\end{array}$ \\
\hline $\begin{array}{l}\text { Cassia } \\
\text { S. fistula }\end{array}$ & $\begin{array}{l}\text { Odu, IFE, 3071, Moor Plantation, Ibadan Oyo State. } \\
\text { Ogunyemi, IFE 3069, Moor Plantation, Ibadan, Oyo State. } \\
\text { Okeke, FHI, 44305, Forest Research Headquarters Ibadan Oyo State. } \\
\text { Ajulo, FHI, 102265, Near Oduduwa Hall, University Ife, Ile-Ife, Osun State. } \\
\text { Saheed, 154, Academic Area FUTA, Akure, Ondo State (IFE) } \\
\text { Saheed, 171, Along Sonde Road, Ilorin, Kwara State (IFE) }\end{array}$ \\
\hline C. siberiana & $\begin{array}{l}\text { Daramola, IFE 13057, Between Orile Ilugun and Olokemeji, Ogun State. } \\
\text { Medler, IFE 3075, Central Borgu Game Reserve, Ilorin, Kwara State. } \\
\text { Oguntayo et al. FHI 89593, Yankari Games Reserve, Bauchi State. } \\
\text { Soladoye, FHI 93054, Between School of Forestry and Main Office Ibadan, Oyo State. } \\
\text { Saheed, 109, Around Oduduwa Hall, Complex O.A.U. Ile-Ife Osun State. (IFE) } \\
\text { Saheed, 182, Beside Ansar-Udeen Primary School Ijebu-Ode Ogun State. (IFE) }\end{array}$ \\
\hline
\end{tabular}

the base, they are glabrous. The petiole is mostly round $2.5-14.6 \mathrm{~cm}$ long. Leaf is pinnate, paripinnate, exstipulate leaflets arranged in 3 pairs oppositely $2.4-4.8 \mathrm{~cm}$ long and $0.6-2.3 \mathrm{~cm}$ wide obovate, margin entire, base acute, apex obtuse. Venation consists of primary veins that are straight in course with lateral veins about 5-8 pairs per leaflet often alternate, more prominent on abaxial surface. The inflorescence is a raceme (Tab. 3), sometimes solitary, axillary 
Tab. 2. Summary of the important vegetative morphological characters

\begin{tabular}{|c|c|c|c|c|c|c|c|c|c|c|c|c|c|c|c|c|c|c|c|c|c|c|c|c|c|c|c|c|c|c|c|}
\hline \multirow[t]{2}{*}{ Characters } & \multicolumn{5}{|c|}{ Plant Habit } & \multicolumn{5}{|c|}{ Leaf Shape } & \multicolumn{9}{|c|}{ Leaf Apex } & \multicolumn{4}{|c|}{ Leaf Base } & \multicolumn{4}{|c|}{$\begin{array}{c}\text { Leaf } \\
\text { margin }\end{array}$} & \multicolumn{2}{|c|}{ Stipule } & \multicolumn{2}{|c|}{ Leaf $(\mathrm{cm})$} \\
\hline & 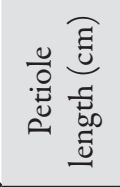 & $\stackrel{\mathscr{ٌ}}{\uplus}$ & 泀 & 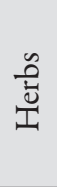 & 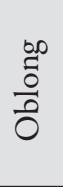 & 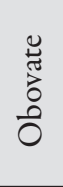 & రัّ & 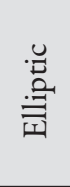 & 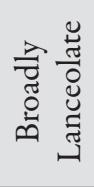 & 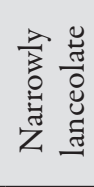 & 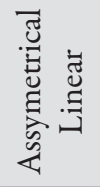 & 远 & 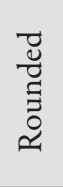 & 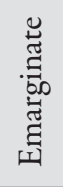 & 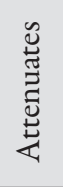 & 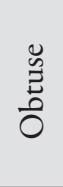 & 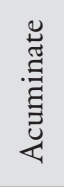 & 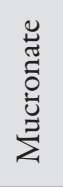 & 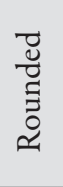 & 苞 & 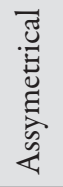 & $\begin{array}{l}\ddot{y} \\
\stackrel{2}{0} \\
0\end{array}$ & 苞 & 莺 & $\stackrel{\overrightarrow{0}}{\Xi}$ & 营 & 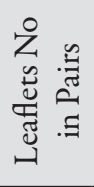 & $\begin{array}{l}\text { 苟 } \\
\text { 完 }\end{array}$ & 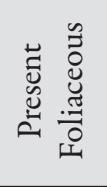 & $\begin{array}{l}\text { పే } \\
\text { ప్ర } \\
\text { త్ర }\end{array}$ & $\frac{5}{0}$ \\
\hline $\begin{array}{l}\text { Senna } \\
\text { S. alata }\end{array}$ & $2.6-10$ & - & + & - & + & + & - & - & - & - & - & - & + & + & - & - & - & - & + & - & - & - & - & + & & - & $5-12$ & + & - & $6-18$ & $4.4-11$ \\
\hline S. hirsuta & $3.8-5.8$ & - & + & - & - & - & + & - & + & - & - & - & - & - & + & - & - & - & - & + & - & - & - & + & + & + & $4-5$ & + & - & $4.5-11$ & $2.6-5.2$ \\
\hline S. obtusifolia & $2.5-14.6$ & - & + & - & - & + & - & - & - & - & - & - & - & - & - & + & - & - & - & + & - & - & - & + & - & - & 3 & + & - & $2.4-2.8$ & $0.6-2.3$ \\
\hline S. occidentalis & $4.6-6.3$ & - & + & - & - & - & + & - & + & - & - & - & - & - & + & - & + & - & - & + & - & - & - & + & - & - & $4-5$ & + & - & $4.3-11.4$ & $1.5-3.0$ \\
\hline S. sophera & $4.6-5.8$ & - & + & - & - & - & - & - & - & + & - & - & - & - & + & - & - & - & - & + & - & - & - & + & & - & $6-9$ & + & - & $4.1-7.3$ & $0.8-1.7$ \\
\hline $\begin{array}{c}\text { Chamaecrista } \\
\text { C. kirkii }\end{array}$ & $0.3-0.5$ & - & + & - & - & - & - & - & - & - & + & - & - & - & - & - & - & + & - & - & + & - & - & + & - & - & $16-38$ & - & + & $0.8-1.3$ & 0.2 \\
\hline C. mimosoides & $0.5-0.5$ & - & + & - & - & - & - & - & - & - & + & - & - & - & - & - & - & + & - & - & + & - & - & + & & - & $25-70$ & - & + & $0.3-0.7$ & $0.1-0.2$ \\
\hline C. rotundifolia & $0.3-0.6$ & - & - & + & - & + & - & - & - & - & - & - & - & - & - & - & - & + & - & - & + & - & - & + & - & - & 1 & - & + & $0.6-2.0$ & $0.4-1.2$ \\
\hline $\begin{array}{l}\text { Cassia } \\
\text { C. fistula }\end{array}$ & $6.5-83$ & + & - & - & - & - & + & - & - & - & - & + & - & - & - & - & - & - & - & + & - & - & - & + & - & - & $7-9$ & + & - & 7.6-18.2 & $4.2-8.3$ \\
\hline C. siberiana & 3-5.6 & + & - & - & - & - & - & + & - & - & - & - & - & - & - & + & - & - & - & - & - & + & - & + & & - & $5-8$ & + & - & $4.3-8.4$ & $2.4-4.3$ \\
\hline
\end{tabular}

(Key: + = present; - = absent) 
Tab. 3. Summary of the important floral morphological characters

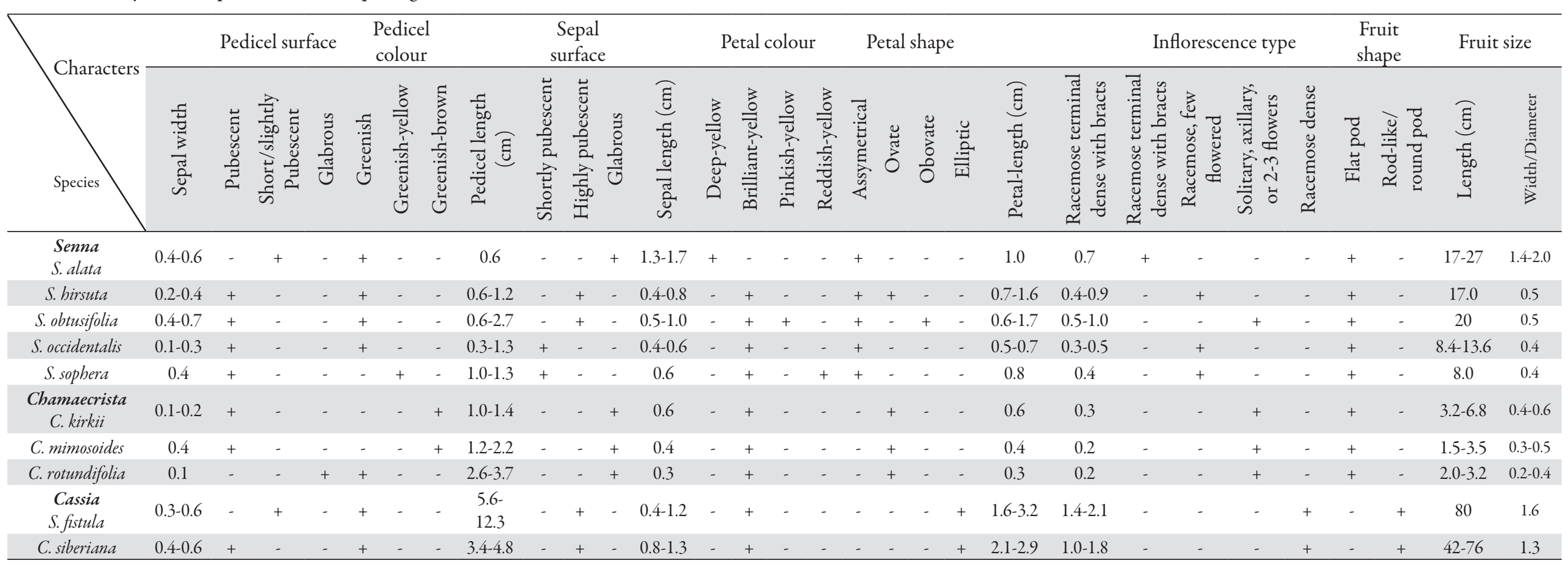

(Key: + = present;-= absent) 
52
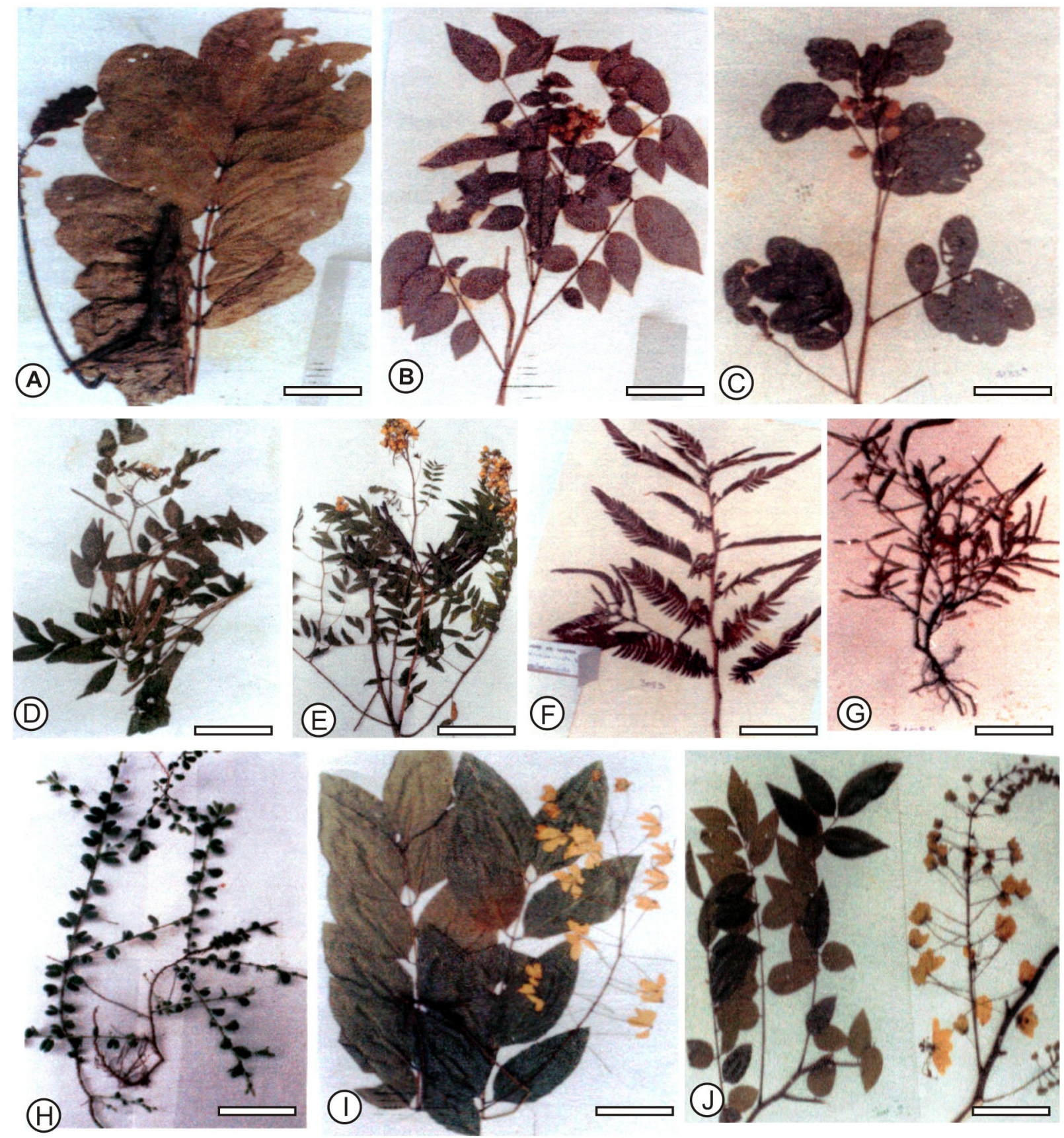

Fig. 1. Prepared herbarium samples of the species studied: $\mathrm{A}=S$. alata $; \mathrm{B}=S$. hirsuta $; \mathrm{C}=$ S. obtusifolia $; \mathrm{D}=$ S. occidentalis $; \mathrm{E}=S$. sophera; $\mathrm{F}=$ C. kirkii; $\mathrm{G}=$ C. mimosoides; $\mathrm{H}=$ C. rotundifolia $; \mathrm{I}=$ C. fistula $; \mathrm{J}=$ C. siberiana. Scale bars $=5 \mathrm{~cm}$

or paired. Pedicel is greenish, pubescent $0.6-2.7 \mathrm{~cm}$ long. The sepal is pubescent, greenish yellow, connate at base, pentamerous, mostly ovate, about $0.5-1.0 \mathrm{~cm}$ long and $0.4-$ $0.7 \mathrm{~cm}$ wide. The petal is pinkish-yellow, some brilliantly yellow, pentamerous, obovate few are assymetrical about $0.6-1.7 \mathrm{~cm}$ long and $0.5-1.0 \mathrm{~cm}$ wide. Stamen is about $0.4-$ $1.0 \mathrm{~cm}$ long filament reddish brown, anther brown. Style is light green, about $1.5 \mathrm{~cm}$ long, stigma dark brown. The fruits are a brownish pod (Tab. 2), polygonal in shape about $20 \mathrm{~cm}$ long and $0.5 \mathrm{~cm}$ wide, apex acuminate.
S. occidentalis (L.) Link (Fig. 1D)

This is a common weed found near habitations, along roadsides as well as wastelands. They are shrub, suffrutescent up to $1.5 \mathrm{~m}$ tall (Tab. 2), mostly annuals, sometimes they are biennials. The stem is greenish at the top and grayish to brown at the base, with glabrous surface. Petiole is polygonal $4.6-6.3 \mathrm{~cm}$ long. The leaf is pinnately compound, paripinnate, exstipulate leaflets 4-5 pairs arranged oppositely, the top pair being the largest about $4.3-11.4 \mathrm{~cm}$ long and $1.5-3.0 \mathrm{~cm}$ wide, broadly lanceolate to ovate. The mar- 
gin is entire, base acute, apex mostly attenuate sometimes acuminate (Tab. 2). Venation consists of primary veins that are straight in course, the lateral veins are about 7-14 in pairs per leaf, and they are mostly alternate, more prominent on the abaxial. Inflorescences are a raceme (Tab. 3), flowers are few in number, the pedicel is green, pubescent about $0.3-1.3 \mathrm{~cm}$ long. Sepals are greenish-yellow sparsely pubescent, connate at base, pentamerous, lanceolate about $0.4-0.6 \mathrm{~cm}$ long and $0.1-0.3 \mathrm{~cm}$ wide. The petal are brilliant yellow, pentamerous, asymmetrical in shape, about 0.5-0.7 cm. Stamen is about 0.6-1.2 cm long, filament greenish -yellow, anther brownish yellow. Style and stigma are greenish up to $1.3 \mathrm{~cm}$ long, the stigma is dark brown. The fruit is a flat pod (Tab. 2), dark-grey in colour about $8.4-13.6 \mathrm{~cm}$ long about $0.4 \mathrm{~cm}$ wide.

\section{S. sophera (L.) Roxb. (Fig. IE)}

A weed commonly found near habitation and farmlands, along roadsides, often found close to $S$. occidentalis. They are shrub (Tab. 2), suffrutescent up to $1.5 \mathrm{~m}$ tall mostly annual, sometimes biennial. Their stem is glabrous, greenish at the top and brownish at the base. Petiole is mostly round about $4.6-5.8 \mathrm{~cm}$ long. The leaf is pinnately compound, paripinnate, exstipulate, leaflets 6-9 pairs arranged oppositely, $4.1-7.3 \mathrm{~cm}$ long and $0.8-1.7 \mathrm{~cm}$ wide, narrowly lanceolate (Tab. 2), margin entire, base acute, apex attenuate, some are very acute. The venation consists of primary veins that is straight in course, lateral veins 8-12 pairs per leaflets, mostly alternate, more prominent on abaxial. Inflorescence is racemose (Tab. 3), few-flowered. Pedicel is greenish yellow, sparsely pubescent $1.0-1.3 \mathrm{~cm}$ long, sepals are shortly pubescent, greenish yellow connate at base; about $0.6 \mathrm{~cm}$ long and $0.4 \mathrm{~cm}$ wide, pentamerous and lanceolate. Petals are brilliant-yellow in colour sometimes they may be reddish yellow, pentamerous, assymetrical in shape about $0.8 \mathrm{~cm}$ long and $0.4 \mathrm{~cm}$ wide. Stamens are about $0.5-1.2 \mathrm{~cm}$ long, the filament is yellowish, anther, is reddish-yellow. The style is light green, about $1 \mathrm{~cm}$ long, while the stigma is dark to brown in colour. The fruit is a flat pod (Tab. 2), dark green in colour about $8 \mathrm{~cm}$ long and $0.4 \mathrm{~cm}$ wide.

\section{Genus Chamaecrista}

\section{C. kirkii (Oliver) Standley (Fig. IF)}

This is a weed that is commonly found on vegetations, lawns, farmlands and along roadsides common on sandy soils. They are erect shrub (Tab. 2), subwoody, grow up to $1.5 \mathrm{~m}$ high. The stem is greenish to reddish brown and they are pubescent. The petiole is mostly round about 0.3 $0.5 \mathrm{~cm}$ long. Stipule is foliaceous, assymetrical in shape, about $0.4-1.0 \mathrm{~cm}$ long and $0.1-0.2 \mathrm{~cm}$ wide, attenuate at the apex, and base is truncate in shape, pubescent. The leaf is pinnately compound (Tab. 2), paripinnate, leaflets, 1638 pairs, oppositely arranged $0.8-1.3 \mathrm{~cm}$ long and about $0.2 \mathrm{~cm}$ wide, asymmetrical, oblong-linear, obliquely acute and mucronate at the apex and asymmetrical at the base, the margin is entire and the leaf is sparsely pubescent. Venation is actinodromous; perfect, basal and reticulate, primary vein is straight in course. The inflorescence is solitary (Tab. 3); sometimes 2-3 flowers occur at the axil. Pedicel is greenish to brown, $1.0-1.4 \mathrm{~cm}$ long, pubescent. Sepal is glabrous, $0.6 \mathrm{~cm}$ long and $0.1-0.2 \mathrm{~cm}$ wide, greenish yellow in colour, pentamerous, lanceolate, and connate at the base. Petals are brilliantly yellow, $0.6 \mathrm{~cm}$ long and 0.3 $\mathrm{cm}$ wide, pentamerous, ovate in shape. Stamens are about $0.3-0.5 \mathrm{~cm}$ long, filaments; greenish yellow, while anther is dark brown. Style is about $0.6 \mathrm{~cm}$ long, greenish yellow stigma dark brown in colour. The fruit is a pod (Tab. 3), 3.2-6.8 $\mathrm{cm}$ long and about $0.4-0.6 \mathrm{~cm}$ wide, brownish to black in colour, greenish when young, flat, linear, oblong, slightly curved and densely pubescent.

\section{C. mimosoides (L.) Greene (Fig. 1G)}

This is a weed commonly found along roadside, as well as in vegetations, farmland and grasslands, common on sandy soil. They are herbaceous (Tab. 2) or low shrub; grow up to $1.5 \mathrm{~m}$ high or sometimes diffuse. The stem is greenish to brown and pubescent. The petiole is mostly round 0.3 $0.5 \mathrm{~cm}$ long. Stipule is foliaceous, assymetrical in shape $0.6-1.3 \mathrm{~cm}$ long and $0.2-0.4 \mathrm{~cm}$ wide attenuate apex, truncate base, pubescent. Leaf is pinnately compound, paripinnate, leaflets $25-70$ pairs oppositely arranged $0.3-0.7 \mathrm{~cm}$ long and 0.1-0.2 cm wide, assymetrical, linear, obliquely acute and mucronate at the apex, assymetrical at the base, margin entire, they are sparsely pubescent (Tab. 2). The venation is actinodromous, perfect, basal and reticulate, primary vein straight in course. Inflorescences are solitary (Tab. 3); sometimes 2-3 flowers occur at the axil. The pedicel is greenish to brown, about $1.2-2.2 \mathrm{~cm}$ long and they are pubescent. Sepals are glabrous, greenish yellow, pentamerous, connate at base, lanceolate, about $0.4 \mathrm{~cm}$ long and 0.1 $\mathrm{cm}$ wide. Petals are brilliant yellow, pentamerous, ovate in shape, about $0.4 \mathrm{~cm}$ long and $0.2 \mathrm{~cm}$ wide. The stamens are about $0.3 \mathrm{~cm}$ long; filament is brownish yellow while anther is dark brown. The style is greenish yellow, about $0.4 \mathrm{~cm}$ long, stigma dark brown in colour. Fruits are a pod, about $1.5-3.5 \mathrm{~cm}$ long (Tab. 3) and about $0.3-0.5 \mathrm{~cm}$ wide, they are dark brown to black, greenish when young, linear, oblong, slightly curved and pubescent.

\section{C. rotundifolia (Pers.) Greene (Fig. 1H)}

They are weed commonly found around habitations, especially growing within grasses on lawns, they are occasionally found in weedy environment, along road side and farmlands. They are herbaceous (Tab. 2), prostrate, about $0.5 \mathrm{~m}$ long or more. The stem is greenish in colour, light brown at the base and pubescent. Petiole is round, about $0.3-0.6 \mathrm{~cm}$ long. The stipule is foliaceous, assymetrical in shape up to $0.7 \mathrm{~cm}$ long and about $0.4 \mathrm{~cm}$ wide, attenuate apex and cordate base pubescent. Leaf is pinnately compound, paripinnate, 1 pair leaflets are oppositely arranged, 
54

obovate, assymetrical at base, apex mucronate, $0.6-2.0 \mathrm{~cm}$ long and $0.4-1.2 \mathrm{~cm}$ wide, the margin is entire and the leaf is pubescent (Tab. 2). Venation is actinodromous, basal, perfect and reticulate, primary vein straight in course. Inflorescences are axillary, solitary, or occasionally paired (Tab. 3). Pedicel is greenish, about 2.6-3.7 cm long, glabrous. Sepals are glabrous, greenish yellow, pentamerous, $0.3 \mathrm{~cm}$ long and $0.1 \mathrm{~cm}$ wide. Petals are yellowish, pentamerous, and ovate in shape, about $0.3 \mathrm{~cm}$ long and $0.2 \mathrm{~cm}$ wide. Stamens are about $0.3 \mathrm{~cm}$ long; filament is greenish yellow, while anther is yellowish. Style is greenish yellow, about $0.3 \mathrm{~cm}$ long, while stigma is pale yellow. The fruit is a pod, dark brown or black brown, linear to oblong (Tab. 3 ), slightly curved, about $2.0-3.2 \mathrm{~cm}$ long and $0.2-0.4 \mathrm{~cm}$ wide.

\section{Genus Cassia}

\section{C. fistula L. (Fig. II)}

This is an ornamental plant used as vegetation cover, for shade and decoration. They are Tree, perennial, erect around $15 \mathrm{~m}$ tall (Tab. 2). The stem is brownish to grey, greenish when young and glabrous. Petiole is round, 6.5$8.3 \mathrm{~cm}$ long. The leaf is pinnately compound, paripinnate about $7.6-18.2 \mathrm{~cm}$ long $4.2-8.3 \mathrm{~cm}$ wide, exstipulate, leaflets are arranged oppositely, margin is entire, ovate in shape while the shape of the base and apex is acute (Tab. 2). Venation pattern shows that the primary vein is straight in course, lateral nerves are about 12-24 pairs per leaflet, alternate mostly, more prominent on the abaxial surface. Inflorescence is racemose-Corymb (Tab. 3). Pedicel is greenish in colour, sparsely pubescent, long 5.6-12.3 $\mathrm{cm}$ long. Sepals are pubescent, greenish yellow, connate at base, pentamerous, lanceolate about $0.4-1.2 \mathrm{~cm}$ long and 0.3-0.6 cm wide. Petals are brilliant yellow, pentamerous, elliptic in shape $1.6-3.2 \mathrm{~cm}$ long and $1.4-2.1 \mathrm{~cm}$ wide. Stamens are about 2.2-3.6 cm long; filaments are greenish yellow while anthers are brown. Style is greenish, about $3.6-5.1 \mathrm{~cm}$ long with greenish stigma. Fruit is a pod, black in colour, mostly straight to curved (Tab. 3), rod-like or round in shape, the length varies could be as long as $80 \mathrm{~cm}$ and $1.6 \mathrm{~cm}$ in width.

\section{C. siberiana DC. (Fig. 1J)}

This is an ornamental plant usually planted for shade and decoration. They are trees, perennial, usually about $15 \mathrm{~m}$ high (Tab. 2). The stem is brownish to grey in colour. The petiole is mostly round, about $3-5 \mathrm{~cm}$ long and $0.1-0.4$ $\mathrm{cm}$ wide. Leaf is pinnately compound, paripinnate, exstipulate, about $4.3-8.4 \mathrm{~cm}$ long, $2.4-4.3 \mathrm{~cm}$ wide, the leaflets are in 5-8 pairs, arranged oppositely, margin entire, elliptic in shape, the shape of the base and apex is obtuse (Tab. 2). The venation primary veins are straight in course, lateral veins are about 10-16 pairs per leaflet, mostly alternate, more prominent on abaxial surface. Inflorescence is racemose-Corymb (Tab. 3), the pedicel is greenish in colour, about 3.4-4.8 cm long and they are pubescent. Sepals are pubescent, greenish yellow, connate at the base, pentamerous, lanceolate, about $0.8-1.3 \mathrm{~cm}$ long and $0.4-0.6 \mathrm{~cm}$ wide. Petals are bright yellow, pentamerous, elliptic in shape about $2.1-2.9 \mathrm{~cm}$ long and 1.0-1.8 cm wide. Stamens are about $2.0-5.2 \mathrm{~cm}$ long; filaments are yellow while the anther is brown. Style is greenish, about $4.6-5.8 \mathrm{~cm}$ long, stigma is also greenish. Fruits are a pod, black, could be straight, sometimes curved (Tab. 3), rod-like or round in shape, apex is acuminate about $42-76 \mathrm{~cm}$ long and about $1.3 \mathrm{~cm}$ wide.

\section{Discussion}

The morphological characters studied in this work correspond largely with those of Hutchison and Dalziel (1958). Watson and Dallwitz (1993) used morphological features in characterizing some genera in LeguminosaeCalsalpinioidea and tribe Swartzieae. However, few salient morphological characters that were not recorded by these authors and which may enhance the taxonomy of these genera and species in Nigeria have been established in this study. The habit encountered in the three genera are variable, members of Senna genus are all shrubs in the five species studied, though Lock (1988) presented the genus as consisting of trees, shrubs or herbs. The Chamaecrista genus consist of shrubs and herbs, C. kirkii and C. mimosoides are shrubs while $C$. rotundifolia is herbaceous, but the Cassia genus are all trees, this results correspond largely with the previous work carried out by Lock (1988). All the species of the three genera are mostly perennial, though there may be combinations of annual, biennials and sometimes perennial habit in the genus Senna, where S. hirsuta, S. obtusifolia, $S$. occidentalis and $S$. sophera integrate the three habits. The only purely perennial in the genus is $S$. alata. In the Chamaecrista genus, all the species are mostly annuals and sometimes biennials while all Cassia species are perennials.

The shape of the leaflet apex varies in the species of Senna, while it is rounded and sometimes emarginated in $S$. alata, it is attenuate in $S$. hirsuta, $S$. sophera and $S$. occidentalis, although acuminate apex sometimes occur in $S$. occidentalis while in S. obtusifolia the apex is mainly obtuse. In the genus Chamaecrista, the leaflet apices are distinctly mucronate whereas in the Cassia genus acute apices are found in C. fistula while it is obtuse in C. siberiana. Interestingly, the leaflet base is quite delimiting for the three genera, it is acute in the species of Senna except in $S$. alata where it is rounded. Assymetrical base is found in all the three species of Chamaecrista studied, however, there are variations with the Cassia genus with $C$. fistula being acute while $C$. siberiana is obtuse.

Recently, Kahraman and Doğan (2010) used leaf morphological characters to separate two closely related species of Salvia in Turkey. Hitherto leaflet numbers which are found taxonomically useful in this study was not been 
used by previous authors like Hutchison and Dalziel (1958) and Irwin and Barneby (1981) as distinguishing characters. In this study, the leaflet pairs differ and ranges from three pairs found in S. obtusifolia to 5-12 pairs that are found in S. alata for the Senna species. In Chamaecrista genus, it ranges from 1 pair found in C. rotundifolia to 25-70 pairs in C. mimosoides while in Cassia it ranges from 5-8 pairs found in C. siberiana to 7-9 pairs that are present in C. fistula. Similarly, lateral nerves can be used taxonomically to distinguish species. In Senna genus the number ranges from 5-8 pairs in S. obtusifolia to 9-23 pairs that is found in $S$. alata, in the Chamaecrista genus, the range is from 4-7 pairs that occurs in $C$. mimosoides to 6-12 pairs that occurs in C. rotundifolia, while in Cassia genus it is from 10-16 pairs found in C. siberiana to 12-24 pairs that is present in C. fistula.

The presence of foliaceous stipule in the genus Chamaecrista separate it clearly from the other two genera-Senna and Cassia-which are completely exstipulate. Pedicels are generally pubescent in all the three genera except in C. rotundifolia where it is glabrous. The colour of the pedicels are mostly greenish in all the genera but greenish yellow in $S$. sophera and greenish brown in C. kirkii and C. mimosoides. The degree of hairiness in sepals is also distinctive, in Senna genus, the sepals are glabrous in $S$. alata, densely pubescent in $S$. hirsuta and $S$. obtusifolia but it is pubescent in $S$. occidentalis and $S$. sophera. The sepals are all glabrous in Chamaecrista genus while they are densely pubescent in Cassia species studied. The shape of the petals is very delimiting in the three genera. Assymetrical petals are common in Senna genus except in $S$. hirsuta where it is sometimes ovate while obovate petals can be encountered in $S$. obtusifolia. In the genus Chamaecrista petals are generally ovate while in Cassia species they are elliptic. Floral parts characters have been found useful in delimiting species in the genus Salvia (Celep and Doğan 2010; Kahraman and Doğan, 2010) and the two Turkish subspecies of Astrantia maxima (Kaya, 2003).

Several authors have emphasized the usefulness of inflorescences in characterizing plants species (Hutchison and Dalziel, 1958; Okpon, 1969 a and b; Kaya, 2003; Celep and Doğan 2010; Kahraman and Doğan, 2010). The type of inflorescence encountered in the three genera studied in this work can clearly differentiate them. Solitary, axillary inflorescence and occasionally 2-3 flowers are found in Chamaecrista genus, whereas dense racemose (Corymb) is a common feature in all Cassia, but in Senna genus there are variations. Few flowered raceme are present in $S$. hirsuta, S. occidentalis and S. sophera, terminal raceme with bracts are found in $S$. alata while solitary, axillary flowers is a common feature in S. obtusifolia although sometimes it may contain 2-3 flowers. The fruit shape is equally important in the delimitation of the species of Cassia genus studied which are characterized by round and rod-like pod unlike in the Chamaecrista and Senna genera that are characterized by pods that are flat in nature. Of importance is the length of the fruits, in Senna species, it ranges from $8.0-27.0 \mathrm{~cm}$ with $S$. sophera having the lowest length of about $8.0 \mathrm{~cm}$ while $S$. alata having the longest range of $8.0-27.0 \mathrm{~cm}$. in Chamaecrista genus the length ranges from 1.5-6.8 $\mathrm{cm}$ with C. mimosoides having the lowest range of $1.5-3.5 \mathrm{~cm}$ and $C$. kirkii having the highest range of 3.2$6.8 \mathrm{~cm}$ whereas in Cassia genus the range is between 42-80 $\mathrm{cm}$ long with $C$. siberiana having about $42-76 \mathrm{~cm}$ while $C$. fistula have a length of $80 \mathrm{~cm}$ long.

In summary, irrespective of the fact that some of the characters measured overlaps, which is still an indication of some relative closeness of these genera and their species, leaf anatomical characters have been shown previously (Saheed and Illoh, 2010) to be useful in the delimitation of these same genera and species. The current work like the previous leaf anatomical studies (Saheed and Illoh, 2010) also justifies the separation of Senna and Chamaecrista from their initial Cassia genus thereby supporting the work of Irwin and Barneby (1981). To delimit these genera, morphological characters that were found to be useful in this study includes habit, leaflet apex and base, presence and absence of stipule, hairiness of sepals and the types of inflorescence, while those characters that could be employed in separating species include leaflet shape, apex, number in pairs, length and width as well as the length of the fruit.

\section{References}

Adebowale A (2000). Biosystematics Studies in Four Suffrutescent Species of Cassia Linn. M. Sc. Thesis submitted to the Department of Botany, Obafemi Awolowo University, Ile-Ife (Unpublished).

Airy-Shaw HK (1973). A dictionary of the flowering plants. $8^{\text {th }}$ edition, Cambridge University Press, London.

Ayensu EZ (1978) Medicinal Plants of West Africa. Reference Publication Inc. Michigan USA.

Bentham G (1871). Revision of the genus Cassia. Transaction of the Linnaean Society London 27:503-591.

Bentham G, Hooker JD (1876). Genera Plantarum. Chapman and Hall Publishers, London.

Celep F, Doğan M (2010). Salvia ekimiana (Lamiaceae), A New Species from Turkey. Annales Botanici Fennici 47:63-66.

Distasi LC, Santos EMG, DosSantos CM, Hiruma CA (1989). Plants Mediccina Isna Amazonia. Editora UNESP. Sao Paulo.

Hutchison J, Dalziel JM (1958). Flora of West Tropical Africa. Vol I part 2. The Whitefraius press Ltd. London.

Irwin HS, Turner BL (1960). Chromosomal relationship and taxonomic consideration in the genus Cassia. American Journal of Botany 47:309-318.

Irwin HS, Barneby RC (1981). Cassieae. In Advances in Legume Systematics (R. M. Polhill and P. H. Raven Eds) Part 1:97106. Royal Botanical Gardens, Kew. 
56

Irwin HS, Barneby RC (1982). Review of Cassinae in the New World. Memoirs of the New York Botanical Garden 35:1 918.

Kahraman A, Doğan M (2010). Comparative study of Salvia limbata C.A. and S. palestina Bentham (sect. Aethiopis Bentham Labiatae) from East Anatolia, Turkey. Acta Botanical Croatica 69(1):47-64.

Kaya A (2003). The genus Astrantia L. in Turkey: morphology and anatomy Acta Botanica Croatica 62(2):89-102.

Lock JM (1988). Cassia sen. Lat. (Leguminosae-Caesalpiniodeae in Africa). Kew Bulletin 43(2):333-342.

Okpon ENU (1969a). Morphological notes on the genus Cassia: I. Notes from the Royal Botanic Garden. Edinburg: 185-195.

Okpon ENU (1969b). Morphological notes on the genus Cassia: II and III. Notes from the Royal Botanic Garden. Edinburg: 331-338.
Olorode O (1984) Taxonomy of Flowering Plants. Longman Inc. London.

Oloruntoba GO (1984). Genetic Studies on Cassia occidentalis L. MSc. Thesis submitted to the Department of Botany, Obafemi Awolowo University, Ile-Ife (Unpublished).

Saheed SA, Illoh HC (2010). A Taxonomic Study of some Species in Cassiinae (Leguminosae) using Leaf Epidermal Characters. Notulae Botanicae Horti Agrobotanici ClujNapoca 38(1):21-27.

Watson L, Dallwitz MJ (1993). The Genera of LeguminosaeCalsalpinioidea and Swartziae: Description, Identification and Information Retrieval. Version: $22^{\text {nd }}$. 